\title{
The Effect of Circuit Learning on Improving The Physical Fitness of Elementary School Students
}

\author{
Gatot Jariono ${ }^{1 *}$,Haris Nugroho ${ }^{2}$, Iwan Hermawan ${ }^{3}$, \\ Fahmy Fachrezzy ${ }^{4}$, Uzizatun Maslikah ${ }^{5}$ \\ ${ }^{1}$ Sport Education, Teacher Training and Education Faculty, Universitas Muhammadiyah \\ Surakarta, IndonesiaIndonesia. \\ ${ }^{2}$ Sports Training Education Study Program,Faculty of Sports, Universitas SebelasMaret \\ Surakarta, Indonesia. \\ ${ }^{3}$ Sports Science Study Program, Faculty of Sports Sciences, Universitas Negeri Jakarta, \\ Indonesia \\ ${ }^{4}$ Sports Education Study Program, Postgraduate Program, Universitas Negeri Jakarta, \\ Indonesia \\ ${ }^{5}$ Sports Branch Training Study Program, Faculty of Sports Sciences, Universitas Negeri \\ Jakarta, Indonesia \\ ${ }^{*}$ Corresponding author: \\ Email: gj969@ums.ac.id
}

\begin{abstract}
.
The purpose of this study is to determine the influence of circuit learning on improving the physical fitness of elementary school students. This research was conducted at SDN 135 SajoangingWajo Regency of South Sulawesi Province, with a sample of 20 people. The method used in this study is to use asi experiments. The data analysis technique used in this study is to use descriptive analysis and inference analysis, descriptive analysis is used to describe the results of this study while inference analysis uses uji_t with a significant degree $\alpha=0.05$ analysis used with the help of SPSS version 20.0. The results of this study found that circuit learning had a significant influence on improving the physical fitness of elementary school students. Thus, it can be concluded that circuit learning is one of the alternatives to improving the physical fitness of school students.
\end{abstract}

Keywords:circuit learning, physical fitness.

\section{INTRODUCTION}

One indicator to maintain good physical fitness is to do physical activity. Physical activity is a sports activity that a person does to maintain physical fitness to do the next activity without experiencing significant fatigue. To do the physical activity it takes motivation to do sports activities. According to Jariono that sports motivation is an encouragement that arises both from within and outside one's self to do sports activities[1]. Furthermore Jariono suggests that sports activities are a series of deliberate movements to improve physical fitness so that harmony and harmony form for the sake of a healthy and fit body, thus for the successful implementation of this task there needs to be conformity between the conditions that must be met that is 
anatomical and physiological to the kind and intensity of physical tasks and motivation to carry out sports activities that must be carried out[2], [3].

Physical activity is one of them is through sports activities related to physical education learning and sports that are enforced in elementary school. Elementary school is the basic foundation for maintaining good physical fitness, to maintain physical fitness required a circuit learning approach. Circuit learning is a learning play with a fun approach to learning.

One of the containers to apply circuit learning in schools to improve body immunity and physical fitness is the learning of physical education, sports, and health. In PJOK learning one of the studies to foster a healthy lifestyle is to apply fun learning that is in nature through playing following the characteristics of elementary school students to shape physical fitness, especially elementary school students. Jariono stated that PJOK learning taught in schools has a very important role, which is to provide opportunities for students to be directly involved in various learning experiences through physical activities to form a healthy quality of life.[3] This is in line with the opinion that one of the objectives of learning physical education, sports, and health in elementary school is basic motion skills and abilities. The basic motion has an important role in the learning of physical education, especially sports that demand displacement of places or weight points such as sprinting, long jump, high jump, and other sports.

One of the objectives of learning Physical Education and Sports is to maintain physical fitness through physical activity one of the most important aspects to maintain the stability of the body as a whole that provides the ability of the body to follow the next activity without experiencing any significant fatigue. Physical fitness in his research found that physical fitness is one of the supporting physical components to improve citation[4]-[6]. This is in line with that physical fitness is a person's physical ability to do one's activities without experiencing significant fatigue and support the stability of the body. To maintain the physical fitness of elementary school students, learning is required with a playful approach[7]-[11]. One approach to learning with a playful approach is circuit defense.

According to circuit learning suggests that circuit learning according to learning is divided into 6-9 stations formed with circular formations carried out with a play activity approach arranged in sequence, thus giving rise to fun learning[12], [13], (Handayani \& Budiyono, 2018),[15]. This is in line with what was stated in circuit training method is carried out in 9 to 12 training post protocols, where participants perform moderate-intensity exercises in a certain number of reps or times in one post and move to the next training post with a short rest time[16]-[18].

That circuit practice is a sequence of activities consisting of 4-12 posts. This is in line with stated that circuit practice is a form of training consisting of several stations or posts and in each station, an athlete performs a predetermined type of exercise. Suharjana further stated that the circuit training program was carried out at 8 
training stations. Each station consists of an exercise that is done for 45 seconds, and the training reps between 15-20 times, the rest time in one station before moving to the next station is 1 minute or less[9], [19]-[24],. This opinion is in line with (stated that one of the advantages of circuit learning is to increase students' creativity in receiving materials provided by teachers, thus affecting the learning outcomes of attitudes and skills.

Based on phenomena in the form of facts faced today, namely: 1) the ease of accessing online games makes students even to do motion activities, 2) lack of physical activity, because it is facilitated with technological advances one of which is to do sports activities are no longer needed more physical activity because the presence of online games make someone, especially elementary school students spend more time to play online games and many more things that need to be studied through scientific research.

Thus, one of the learning with this circuit learning model approach is expected to stimulate students' physical fitness. Related to this, the update of this research is to improve physical fitness, one of which is through learning to play through the approach of circuit practice. In-circuit learning invites students to be active and always cheerful in the learning process that plays following the characteristic of elementary students. From this problem, researchers believe that researching by looking at a person's physical fitness makes a person more enterprising to do a physical activity outside the home. The solution offered in this study is the influence of circuit learning on improving the physical fitness of elementary school students.

\section{METHODS}

This type of research is pseudo-experimental research, as this research was conducted in January-March 2020 at SDN 135 SajoangingWajo Regency, South Sulawesi Province, while the target of this research is all students of SDN 135 Akkajeng while the research subjects of SDN 135 Akkajeng 20 sons, the design of this study can be seen in figure 1 .

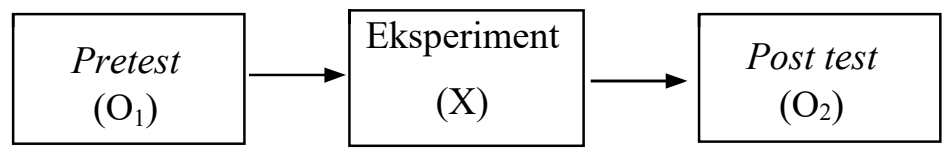

Fig.1. Research design

In this research there are several steps taken, namely " (1) establish the research subject group; (2) conduct pre-test (O1); (3) Treating circuit learning models; (4) Conduct post-test $(\mathrm{O} 2)$; (5) look for pre-test and post-test average scores and be compared between the two; (6) look for the difference between the two averages through the statistic method (t-test) "to determine whether or not there is a significant influence of the learning approach using a play approach for elementary school students". 
Quasi-experimental research using a single-subject design was done by giving tests to subjects who had not been treated called pretests $\left(\mathrm{O}_{1}\right)$. After obtaining the data of students who have preliminary data, it is treated using a circuit learning approach within 8 weeks. Then performed treatment to students, then given again a test called $\left(\mathrm{O}_{2}\right)$ to measure whether or not the influence of circuit learning models given to physical fitness $(\mathrm{X})$, in the post-test obtained data results from experiments where students' physical fitness ability increased or no change at all. The population and sample of this study were elementary school students of 135 AkkajengWajoDistrict of South Sulawesi Province grade IV and V using a male sample of 20 students. Data collection techniques using the physical fitness instrument AAHPER (American Association for Health, Physical Education and Recreation) megadoses from Don R. Kirkendall, Joseph J Gruber and Robert E. Johnsen (1980:268) in jariono dissertations (2015) consists of (1) Pull-ups elements measured Dynamic muscles and endurance;(2) Flaxed arm hang elements measured Muscle synthesis short endurance (for women) (3) Sprint (50 meters) elements measured Power speed;(4) Sit-ups 41 (one minute) measured element Dynamic muscles, endurance: medium (5) standing board jump elements measured power;(6) Shuttle run elements measured Dynamic muscles, endurance: medium, and (7) Running and walking 600 yards $(548.78 \mathrm{~m})$, walking and running 9-12 minutes with distance 1 mile $(1,609.76 \mathrm{~m}$ or $2 \mathrm{~km})$ to run $1 \frac{1 / 2}{2}$ miles $(2,414.64$ meters or $3 \mathrm{~km})$ of dynamic muscle measured elements, durability: medium combined with speed. After the physical fitness test data is obtained, then a T_skor test (Tskor $=50 \pm(\mathrm{X}-\mathrm{x} / \mathrm{SD})$ where $\mathrm{X}$ is the initial score, $\mathrm{x}$ is the average score, and SD is the standard deviation of the score obtained as a whole. T_skor is to equate units in physical fitness tests. Furthermore, data from physical fitness tests are analyzed using t-tests. Overall data analysis using spss software version 20.0 for windows.

\section{RESULT AND DISCUSSION}

\section{A. RESULT}

\section{Descriptive data}

Descriptive analysis of data aims to draw a general picture of the dissemination of distributions from the "pretest and posttest" physical fitness of elementary school students. Before being analyzed, both descriptively and inferentially, unit equality is carried out through T_Skor. A recap of the results of the descriptive analysis of data can be seen in Table 1.

Table 1. Results of descriptive analysis of physical fitness "pretest and posttest"

\begin{tabular}{lcc}
\hline \multirow{2}{*}{ Statistics } & \multicolumn{2}{c}{ Physical fitness } \\
\cline { 2 - 3 } & Pretest & Posttest \\
\hline Number of Samples & 20 & 20 \\
Average value & 9.70 & 16.40 \\
Range & 5 & 2 \\
Minimum Value & 8 & 15
\end{tabular}




\begin{tabular}{lcc} 
Maximum Value & 13 & 17 \\
Total Number & 194 & 328 \\
\hline
\end{tabular}

Based on the descriptive analysis results in table 1 it can be concluded that there is an increase in pretest and posttest physical fitness of students who follow the extracurricular volleyball game. This is evidenced from 20 samples obtained the average pretest and posttest values of 9.70 and 16.40, range values for pretests and postest of 5 and 2, obtained minimum pretest and posttest values of 8 and 15, pretest and posttest maximum values of 13 and 17, and obtained the total number of pretests and posttests of 194 and 328. Thus, it can be concluded that there is an average score increase of 6.70 on the application of circuit learning to improve the physical fitness of students of SDN 135 Sajoanging Subdistrict of Wajo District of South Sulawesi Province by 9.70 and 16.40 has a total of 6.70 . thus it can be concluded that there is an increase of 6.70 levels of physical fitness after being treated with the application of circuit learning. Furthermore, after obtaining a descriptive analysis of frequencies to strengthen the findings in the field can be seen histogram average value of "pretest and posttest" physical fitness of students in figure 2 .

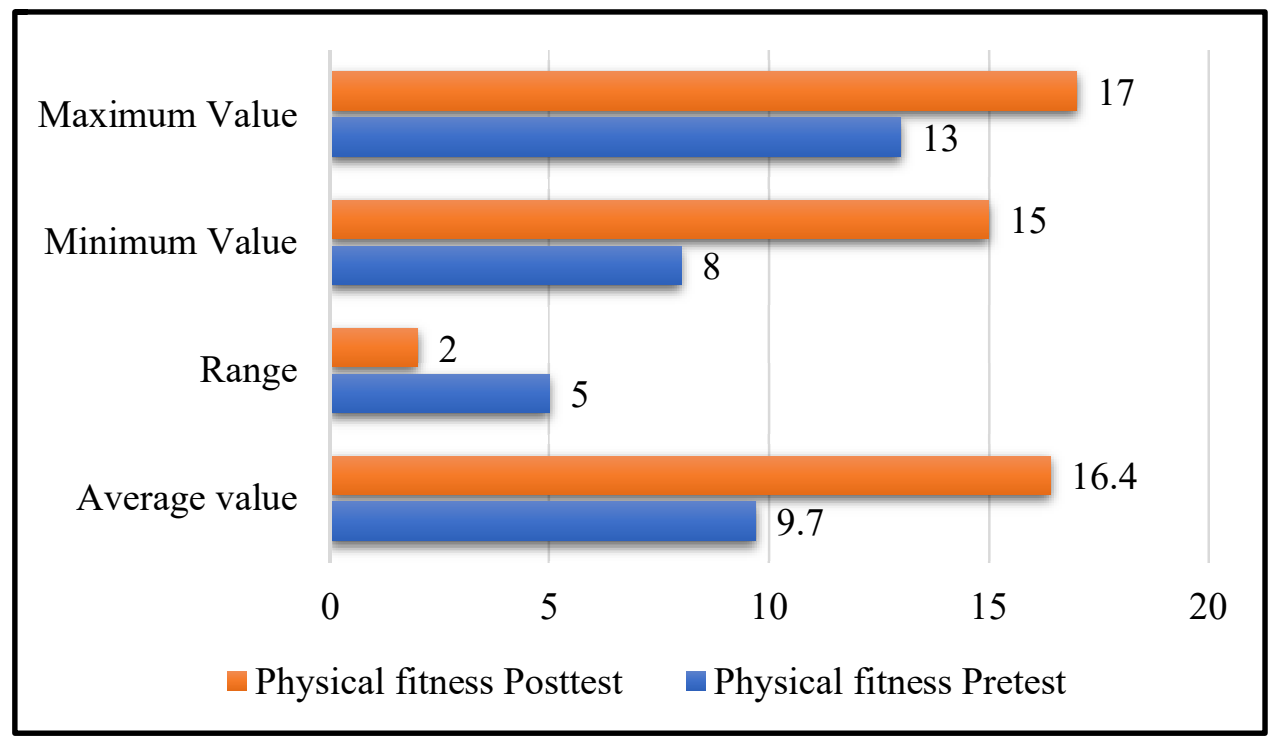

Fig. 2. Pretest and posttest physical fitness

To prove the significance of the influence of circuit learning models on improving the physical fitness of elementary school students, it is necessary to conduct statistical testing with a "t-test". After the descriptive analysis results are described thoroughly, it is continued with the normality test data using the Kolmogorov-Smirnov Z (KS-Z) test at a significant level of $\alpha=0.05$ as a prerequisite for the research hypothesis test, while the normality results of research data can be seen in the normality test table.

\section{Data Normality Test}

Table 2. Results of normality data "pretest and posttest" physical fitness students 


\begin{tabular}{|c|c|c|}
\hline \multirow{2}{*}{ Statistics } & \multicolumn{2}{|c|}{ Physical fitness } \\
\hline & Pretest & Posttest \\
\hline Number of Samples & 20 & 20 \\
\hline Kolmogorov-Smirnov Z & 1.166 & 1.507 \\
\hline $\begin{array}{l}\text { Asymp, what's going on? } \\
\text { Sig. (2-tailed) }\end{array}$ & .132 & .121 \\
\hline
\end{tabular}

Based on the data normality test results in the Kolmogorov-Smirnov Z (KS-Z) value table in the entire data group was greater than the value of $\alpha=0.05$. Thus it can be concluded that the sample of this study comes from a normally distributed population. This conclusion implies that parametric statistical analysis can be used to test the hypotheses proposed in this study so that the first requirements for hypothesis testing have been met. Furthermore, the homogeneity test was done with the Barlett test at $\alpha=$ 0.05. recapitulation of homogeneity analysis results with Barlett test using OnewayAnova test of homogeneity of variances analysis presented on the homogeneity test table.

\section{Homogeneity Test}

Table 3. Homogeneity test results

\begin{tabular}{llll}
\hline Group & $\chi^{2}$ & $\chi^{2}$ table $\alpha=0.05$ & Sig. (p) \\
\hline Pretest & 2.711 & 31.410 & 0.108 \\
Posttest & & &
\end{tabular}

The test results indicated Levene test results obtained a value of 2,711 and $\mathrm{p}=$ $0.108>\alpha 0.05$ or the test indicated that the value of 2 counts $=2,711$ is smaller compared to the value of 2 tables $=31,410$ with a significant level $(p)=12,711$ so that it is concluded that the eight data groups tested came from populations with homogeneous variance. Based on the two test results the above analysis requirements provide the conclusion that the analysis requirements required for variance analysis are met so that it is feasible to conduct further analysis in looking at the effect of the application of circuit learning models on improving the physical fitness of students of SDN 135 Sajoanging Subdistrict Wajo, South Sulawesi Province. Furthermore, for the variance linearity test in both groups of design one group pretest-posttest design is done with ANAVA test at the level of $\alpha=0.05$, which can be described on the linearity test table.

\section{Linearity Test}

Table 4. Linearity test results

\begin{tabular}{|c|c|c|c|c|c|}
\hline & $\begin{array}{l}\text { Sum of } \\
\text { Squares }\end{array}$ & Df & $\begin{array}{l}\text { Mean } \\
\text { Square }\end{array}$ & $\mathrm{F}$ & Sig. \\
\hline (Combined) & 2.778 & 5 & .556 & .970 & .469 \\
\hline$* \quad+\quad$ Linearity & .065 & 1 & .065 & .113 & .741 \\
\hline Deviation from Linearity & 2.713 & 4 & .678 & 1.184 & .360 \\
\hline ¿ Within Groups & 8.022 & 14 & .573 & & \\
\hline Total & 10.800 & 19 & & & \\
\hline
\end{tabular}


From the table above from the results of the physical fitness pretest linearity test (O1) on physical fitness posttest variable (O2), obtained Fhitung value of 1,184 with a significance level of $0.360>0.05$, this means $\mathrm{H} 0$ received and $\mathrm{H} 1$ rejected. Thus it can be concluded that the form of the regression equation is linear. After the test conditions are met, the next hypothesis test is carried out as for the hypothetical test results to find out the significance of the influence of the application of circuit learning models on improving the physical fitness of students of SDN 135 Sajoanging Subdistrict Wajo Regency of South Sulawesi Province can be seen in the table of the following hypothesis test;

\section{Statistical Test}

Table 5. Results uji_t physical fitness pretest and posttest data

\begin{tabular}{lclc}
\hline Statistics & $t_{\text {-hitung }}$ & Sig. & $t_{\text {-tabel }(0,05)}$ \\
\hline $\begin{array}{l}\text { Differences in pretest } \\
\text { posttest }\end{array}$ & 21.132 & 0.000 & 1.729 \\
\hline
\end{tabular}

Based on analysis of the t-test correlation coefficient in table 5 above obtained $t$ hitung of 21,132 and t_hitung (19(10);0.05) of 1,729. Based on these results, it can be concluded that the correlation coefficient (t-test) between pretest and posttest significant physical fitness improvement or $\mathrm{HO}$ is rejected and received H1. Thus, it can be concluded that there is a significant influence of the application of circuit learning models to improve the physical fitness of students at SDN 135 in Sajoanging Subdistrict, Wajo Regency, South Sulawesi Province. This means that the coefficient can be generalized or can apply to the overall student population where a sample of 20 people is taken

\section{B. DISCUSSION}

The results showed that from descriptive data analysis results to research hypothesis testing, learning used through circuit practice approaches had a significant effect on improving the physical fitness of elementary school students. Physical fitness is a supporting element of a person's physical condition in carrying out daily activities without experiencing significant fatigue.

Based on the results of the study, circuit learning can improve the physical fitness of students at SDN 135 in Sajoanging Subdistrict, Wajo Regency, South Sulawesi Province. These results are supported by the results of research Fikri revealing improving physical fitness through circuit training methods in the learning of physical education of sports and health at SMA Negeri 1 Lubuklinggau[9]. The results of the study were supported by Juliantoin his research found that there was a significant improvement in physical fitness through the training kids circuit in grade VIII students of SMP Negeri 4 Ciawigebang[25]. This research was strengthened by Hakim \&Yudasmarain his research found that there is an increase in students' activeness in physical education learning using play methods for grade $\mathrm{V}$ students at 
SDN 2 Pagelaran[26]. This result was confirmed by the results of the study in his research showing the role of rhythmic gymnastics in the physical fitness of elementary school students[27][28]. Suggests that circuit play is a training model shown so that the working functions of muscle groups work sequentially with the process[9] of delivering games that are deliberately created and formed in circles and consist of several stations. The provision of circuit games is an effort to stimulate and increase students' motivation in participating in PJOK learning supported by research results from Miris \& Efta Budiyonoafter the awarding of circuit games in the learning process there was an increase in learning outcomes carried out through circuit games, it was proven that there was an increase in the results of students' sprint learning that initially before there was the treatment of circuit games only 17 students, then after the awarding of circuit games in the learning process to 26 students.

Thus circuit learning is one of the solutions to be applied in elementary schools especially to improve physical fitness because from the results of this study it was found that circuit learning can improve physical fitness more effectively and efficiently. The learning of this circuit is following the characteristics of the basic school students who are at this age children still enjoy playing.

The advantage of the method is the material is delivered in the form of a game in which there is an element of play so that it makes students feel not bored in the process of delivering the material. Circuit games that are used as a medium in the learning process, circuit game materials that are still rare and rarely even accepted by the students cause the emergence of curiosity from within the students themselves and the emergence of a sense of wanting to learn to be better so that outside stimuli in the form of circuit games successfully motivate students to follow the learning of Physical Education and Sports.

\section{CONCLUSION}

From the results of the study, it can be concluded that the circuit learning model has a significant influence on improving the physical fitness of elementary school students.

\section{REFERENCES}

[1] G. Jariono and N. Subekti, "Sports Motivation Survey And Physical Activity Students Of Sport Education Teacher Training And Education Faculty FKIP Muhammadiyah University Surakarta," Kinestetik J. Ilm. Pendidik. Jasm., 2020, doi: 10.33369/jk.v4i2.12449

[2] G. Jariono and N. Subekti, "Sports Motivation Survey And Physical Activity Students Of Sport Education Teacher Training And Education Faculty FKIP Muhammadiyah University Surakarta," Kinestetik J. Ilm. Pendidik. Jasm., 2020, doi: $10.33369 /$ jk.v4i2.12449.

[3] G. Jariono, F. Fachrezzy, and H. Nugroho, “Application of Jigsaw Type Cooperative Learning Model to Improving the Physical Exercise Students Volleyball at Junior High School 1 Sajoanging," vol. 2, no. 5, 2020. 
[4] T. Suhartoyo, D. R. Budi, M. N. H. Kusuma, M. Syafei, A. D. Listiandi, and R. Hidayat, "Identifikasi Kebugaran Jasmani Siswa SMP Di Daerah Dataran Tinggi Kabupaten Banyumas," Phys. Act. J., 2019, doi: 10.20884/1.paju.2019.1.1.1995.

[5] V. S. Golokova, A. A. Olenova, and N. D. Nikolaev, "Enhancing physical fitnes of wrestlers with hearing impairment by means of hapsagay wrestling," Teor. i Prakt. Fiz. Kult., 2019.

[6] S. Saputra, S. Sugiyanto, and D. Defliyanto, "Studi Kebugaran Jasmani Menggunakan Metode Harvard Step Tes Pada Mahasiswa Penjas Semester Vi Universitas Bengkulu Tahun Akademik 2018-2019," KINESTETIK, 2019, doi: 10.33369/jk.v3i2.8914.

[7] I. Darmawan, "Upaya Meningkatkan Kebugaran Jasmani Siswa melalui Penjas," Jip, 2017.

[8] D. P. Prakoso and Setiyo Hartoto, "Pengukuran Tingkat Kebugaran Jasmani Terhadap Siswa Yang Mengikuti Ekstrakulikuler Bolavoli di SMS DR.Soetomo Surabaya," J. Pendidik. Olahraga dan Kesehat., 2015, doi: 10.1098/rstb.2014.0015.

[9] A. Fikri, "Meningkatkan Kebugaran Jasmani Melalui Metode Latihan Sirkuit Dalam Pembelajaran Pendidikan Jasmani Olahraga Dan Kesehatan Di SMA Negeri 1 Lubuklinggau," J. Pembelajaran Olahraga, 2017.

[10] B. S. Adi, "Meningkatkan Kebugaran Jasmani Anak SD Melalui Latihan Kebugaran Aerobik," Skripsi, 2010.

[11] O. F. Bryantara, "Faktor Yang Berhubungan Dengan Kebugaran Jasmani (Vo2Maks) Atlet Sepakbola,” J. Berk. Epidemiol., 2016, doi: 10.20473/jbe.v4i2.2016.237.

[12] H. Miris and Efta Budiyono, "Pengaruh Metode Permainan Sirkuit Pintar Terhadap Hasil Belajar Matematika Siswa Kelas IV SD Miris,” J. Penelit. Pendidik. Guru Sekol. Dasar, 2013, doi: 10.1017/CBO9781107415324.004.

[13] C. Duffour et al., “Aplikasi Pembelajaran Bermain Menggunakan Model Aktivitas Sirkuit Untuk Meningkatkan Hasil Belajar Tolak Peluru Pada Siswa Kelas X-I Sma N I Pulokulon," J. PINUS, 2017, doi: 10.1177/0309133309346882.

[14] M. HANDAYANI and B. BUDIYONO, "Pengaruh Metode Permainan Sirkuit Pintar Terhadap Hasil Belajar Matematika Siswa Kelas IV SD," J. Penelit. Pendidik. Guru Sekol. Dasar, 2018.

[15] A. N. Cahyo, "Pengembangan Model Permainan Sirkuit Kardio Untuk Meningkatkan Kebugaran Jasmani Pada Anak Usia 6-9 Tahun Andi,” J. Pendidik. Kesehat. rekreasi, 2019.

[16] B. Kilka and C. Jordan, "Circuit Training Using Body Weight :," Heal. Fit. J., 2013.

[17] A. Paoli et al., "Effects of high-intensity circuit training, low-intensity circuit training and endurance training on blood pressure and lipoproteins in middle-aged overweight men," Lipids Health Dis., 2013, doi: 10.1186/1476-511X-12-131.

[18] I. G. L. Van De Port, L. E. G. Wevers, E. Lindeman, and G. Kwakkel, "Effects of circuit training as alternative to usual physiotherapy after stroke: Randomised controlled trial," $B M J, 2012$, doi: 10.1136/bmj.e2672.

[19] Ismaryati, "Penggunaan Metode Kombinasi Latihan Sirkuit-," Progr. Pendidik. POK, FKIP Univ. Sebel. Maret Surakarta, 2008.

[20] M. D. Kurniawan and M. Pudjianto, "Perbedaan Latihan Interval, Sirkuit Training, dan Lari Jarak Jauh terhadap Peningkatan Kebugaran Aerobik pada Atlet Bola Basket di MAN 2 Semarang,” J. Kesehat., 2017, doi: 10.23917/jurkes.v10i1.5491. 
[21] M. F. Robiansyah and F. Amiq, "Pengembangan Model Latihan (Circuit Training) Dalam Permainan Futsal,” Pros. Semin. Nas. IPTEK Olahraga 2018, 2018.

[22] S. Nugroho, "Pengaruh Latihan Sirkuit (Circuit Training) Terhadap Daya Tahan Aerobik (Vo2 Max) Mahasiswa Pko Fakultas Ilmu Keolahragan Universitas Negeri Yogyakarta," J. Ilm. Pendidik. Jasm. Kesehat. dan Rekreasi, 2007.

[23] A. Yani, "Pengaruh Metode Latihan Sirkuit, Metode Konvensional Dan Motivasi Berprestasi Terhadap Kemampuan Lompat Jauh Gaya Jongkok," Prim. J. Pendidik. Guru Sekol. Dasar, 2015, doi: 10.33578/jpfkip.v4i2.2947.

[24] W. A. Ulfah and E. P. Walton, "Pengaruh Latihan Sirkuit Training Terhadap Kecepatan Tendangan Sabit Pada Siswa Ekstrakulikuler Pencak Silat," Sport. J. Phys. Educ. Sport Recreat., 2019, doi: 10.26858/sportive.v2i2.8492.

[25] I. Julianto, "Upaya Meningkatkan Kebugaran Jasmani Melalui Sirkuit Training Kids pada Siswa," JUARA J. Olahraga, 2016, doi: 10.33222/juara.v1i1.56.

[26] L. Hakim and D. S. Yudasmara, "Upaya Meningkatkan Keaktifan Siswa Dalam Pembelajaran Pendidikan Jasmani Menggunakan Metode Bermain Untuk Siswa Kelas V Sdn 2 Pagelaran," TEGAR J. Teach. Phys. Educ. Elem. Sch., 2018, doi: 10.17509/tegar.v1i2.11940.

[27] I. Hamzah, A. Ginanjar, and A. Setiawan, "Pengaruh Model Pembelajaran Jigsaw Terhadap Hasil Belajar Passing Bawah Bola Voli,” J. Kependidikan Jasm. dan Olahraga, vol. 3, no. 1, pp. 58-63, 2019.

[28] A. M. N. Pasaribu and H. Mashuri, "Peranan senam irama terhadap kebugaran jasmani untuk siswa sekolah dasar," J. Sport. J. Penelit. Pembelajaran, 2019, doi: 10.29407/js_unpgri.v5i1.12551.

[29] "Peningkatan Keterampilan Gerak Dasar Melalui Modifikasi Permainan Sirkuit," Act. - J. Phys. Educ. Sport. Heal. Recreat., 2013, doi: 10.15294/active.v2i11.2466.

[30] "Upaya Peningkatan Pembelajaran Tolak Peluru Dengan Pendekatan Permainan Sirkuit Pada Kelas V Sekolah Dasar Negeri 1 Rowosar Kecamatan Rowosari Kabupaten Kendal Tahun 2013," Act. - J. Phys. Educ. Sport. Heal. Recreat., 2014, doi: 10.15294/active.v3i1.2833.

[31] R. B. Utomo, "Sirkuit Hamilton Dalam Permainan Congklak," AdMathEdu J. Ilm. Pendidik. Mat. Ilmu Mat. dan Mat. Terap., 2017, doi: 10.12928/admathedu.v7i1.7400. 